\title{
Weathering of Glass - A Caution for the Use of Recycled Glass in Construction, Infrastructure, and Storage Containers
}

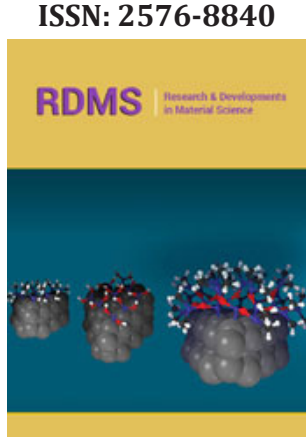

*Corresponding author: Semeniuk $\mathrm{V}$, Department of Arts \& Sciences, The University of Notre Dame, Fremantle, WA Email: vcsrg@iinet.net.au

p.clifford@iinet.net.au

Submission: 海July 09, 2020

Published: 制July 15, 2020

Volume 13 - Issue 5

How to cite this article: Clifford $P$ Semeniuk V. Weathering of Glass - A Caution for the Use of Recycled Glass in Construction, Infrastructure, and Storage Containers. Res Dev Material Sci. 13(5). RDMS.000823. 2020 DOI: $10.31031 /$ RDMS.2020.13.000823

Copyright@ Semeniuk V. This article is distributed under the terms of the Creative Commons Attribution 4.0 International License, which permits unrestricted use and redistribution provided that the original author and source are credited.

\section{Clifford $\mathrm{P}^{1}$ and Semeniuk $\mathbf{V}^{1,2 *}$}

${ }^{1}$ Department of Arts \& Sciences, The University of Notre Dame, Fremantle, Western Australia

${ }^{2}$ V \& C Semeniuk Research Group, Warwick, Western Australia

\section{Opinion}

Weathering occurs in many materials exposed to the weather and near-surface processes. One of the products of weathering can be patina which occurs as a fine layer or encrustation, usually laminated, on the surface of rock or other materials (Jackson 1997). The term 'patina' is also used with reference to the oxidation of metals such as bronze or copper, as well as for the layer on rock surfaces in arid regions (e.g., 'desert varnish', cf. Jackson 1997). Glass is known to be susceptible to weathering (especially the soda-lime-silica glasses; Maloney 1968) and, in subaerial, soil, or aqueous environments, because of its chemical composition, it is subject to weathering producing a characteristic patina that has been the subject of investigation for decades [1-4] (Garcia-Valles et al. 2003).

Clifford \& Semeniuk [4], in a recent publication, documented the vadose-zone weathering of various types of glass from a historic refuse site that is less than 100 years old at Cossack, north-western Australia, located in arid climate coastal dunes. Using SEM, EDS, and XRD, Clifford \& Semeniuk [4], recorded a plethora of dissolution and precipitation structures and features on the glass and in the patina and, most importantly for the purposes of this paper, they reported the resorption and re-solution of patina to result in a complex of features found in relatively young patina. The patina at Cossack is usually $<100 \mu \mathrm{m}$ thick but it provides a high-resolution record which can be used for archaeological dating, reconstruction of shortterm climate history, reconstruction of pedological processes and history, and interpretation of vadose-water hydrochemical history [4]. Some of the most important factors to emerge from the study of patina in the Cossack area were the short-term instability of glass as well as its encrusting patina and the variety of patina products. The products of weathering included: curved, scalloped, jagged, irregular, and straight solution fronts etching into glass as the corrosion invaded the glass ( 2 \& 3 in Figure 1); a patina composed of silica and calcite ultra-fine laminae ( 4 in Figure 1); post-patina alteration including solution of calcite laminae to produce laminoid voids (5A in Figure 1), solution and brecciation of laminae (5B in Figure 1), random small vughs (5C in Figure 1), and micro-unconformities (5D in Figure 1); that is, both glass and patina are susceptible to weathering.

With the recent focus on management of land-fill waste, there has been an emphasis on the recycling of used glass, and while some is used in glass smelts, most waste glass has ended up in refuse sites. In recent years there have been endeavours to find alternative uses for this waste product. Consequently, glass has been recycled as construction material and waste storage materials (bricks - Demir [5]; in a mix with concrete - Seung et al. [6], Topco [7], Alhumoud [8]; storing radioactive waste - McGann et al. [9], Bingham et al. [10]; pavements and roads [mixed with asphalt] - Senadheera et al. 2005, Herrington et al. [11], 
Imteaz et al. [12], Arnold et al. 2008). Recycling of glass in its many aspects is viewed as a very positive step to reduce land-fill waste, and hence glass recycling has grown rapidly over the recent short term. Further, crushed glass can be used for filtration, sand blasting, fiberglass, and decorative items. The Department of Environmental Quality in Montana lists some ten positive aspects of recycling glass [13], including that all glass food/beverage containers can be recycled, that instead of making glass from silica sand, recycling of glass reduces mining waste by $70 \%$, water use by $50 \%$, and air pollution by $20 \%$, that for every 87 tons of recycled glass used, 0.9 tons of carbon dioxide (a greenhouse gas) is reduced, that glass is $\mathrm{pH}$ neutral, and that there appears to be no detrimental health effects with recycled glass.

However, while it appears that recycling of glass would seem to be a very positive outcome for alleviating some of the environmental problems associated with land-fill disposal, glass and its patina are unstable and, exposed to soils and water, are subject to chemical decay. The finer the glass particle formed by crushing glass to sand size $(125-250 \mu \mathrm{m})$ or by pulverizing it to a powder $(\sim 4 \mu \mathrm{m})$ the more susceptible it will be to corrosion. All the solution and precipitation phenomena evident in Figure 1 will occur in recycled crushed and pulverized glass. Thus, there is potential for bricks, concrete, roads, and paving formed from crushed glass to deteriorate relatively rapidly and have a shorter-than-expected structural lifespan. The matter of most concern, however, is when recycled glass is used to manufacture small vitreous containers to store nuclear waste or other forms of contaminated waste. If buried, as often is the case for nuclear waste, such containers will be in contact with groundwater or, at the least, subject to vadose-zone hydrology. The implications are that, due to its instability, when in contact with water, glass will chemically decay, i.e., nuclear waste will be stored in an unstable container which corroborates the conclusions of Frankel et al. [14]. As such, we proffer a note of caution - recycled glass needs to be investigated as to how appropriate it is for its secondary recycled use especially in the storage of nuclear waste, and also in its projected stability in the construction and road-making industries.

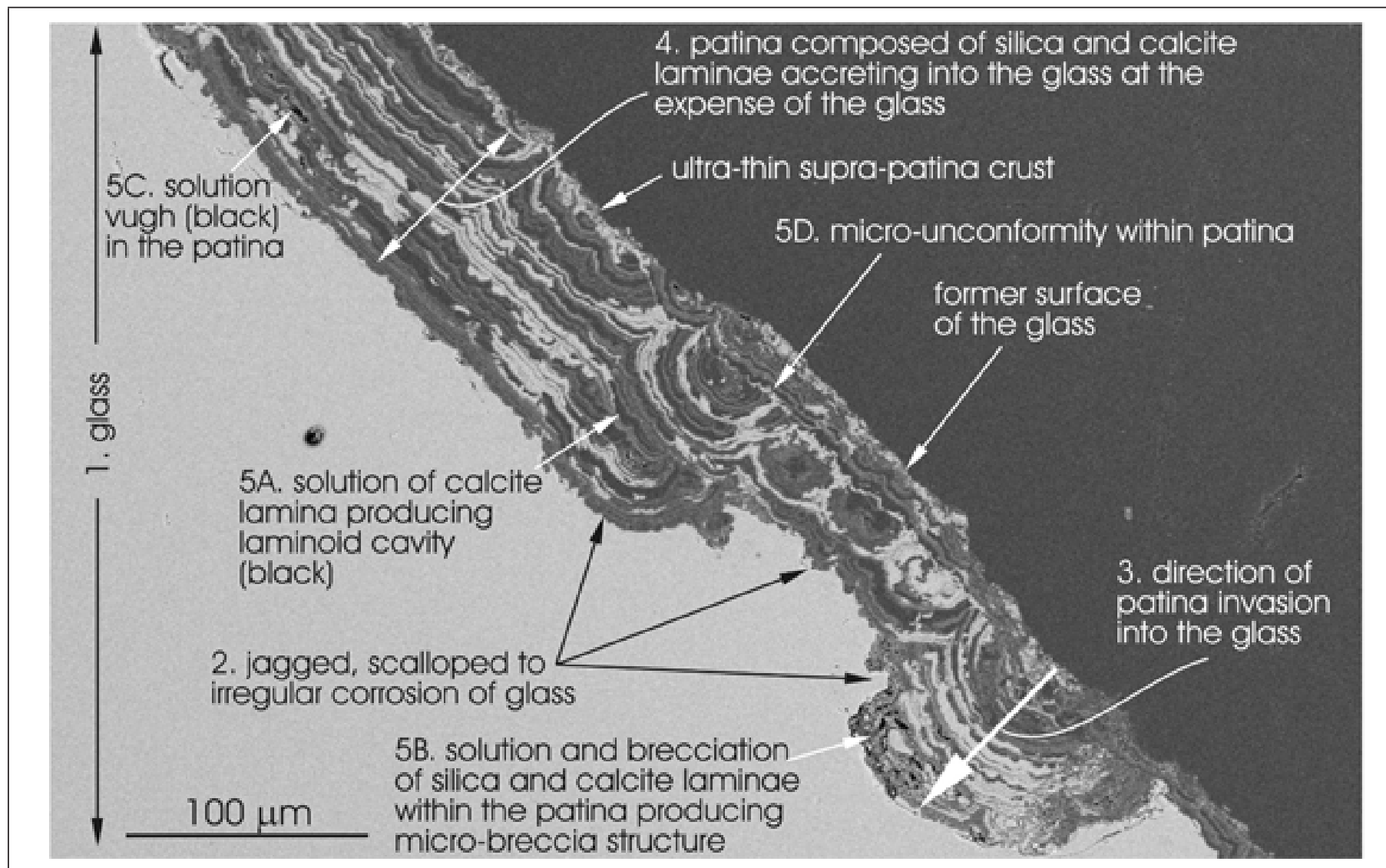

Figure 1: SEM of patina from Cossack showing sequential development of structures in glass and patina through processes of solution and precipitation. Of special note is that the entire patina thickness in this image is $\sim 100 \mu \mathrm{m}$ and individual patina laminae and voids are $\sim 1-2 \mu \mathrm{m}$ in thickness, sizes that are in the range of sand-sized crushed glass and pulverized glass.

\section{References}

1. Brill RH (1961) The record of time in weathered glass. Archaeology 14: $18-22$.
2. Newton R (1976) The weathering of medieval window glass. Journal of Glass Studies 17: 161-168.

3. Cox GA, Ford BA (1993) The long-term corrosion of glass by ground water. Journal of Materials Science 28: 5637-5647. 
4. Clifford P, Semeniuk V (2020) Patina on historic glass: A case study from Cossack, Western Australia: its use in Archaeology, microchemistry, and as a tool for reconstructing pedogenic processes, microchemistry, climate patterns, and chronology. Cambridge Scholars Publishing, Newcastle upon Tyne, UK.

5. Demir I (2009) Reuse of waste glass in building brick production. Waste Management \& Research 27(6): 572-577.

6. Seung BP, Lee BC, Kim JH (2004) Studies on mechanical properties of concrete containing waste glass aggregate. Cement \& Concrete Research 34: 2181-2189.

7. Topcu IB, Canbaz M (2004) Properties of concrete containing waste glass. Cement \& Concrete Research 34(2): 267-274.

8. Alhumoud JM, Terro MJ (2008) Recycling crushed glass in concrete mixes. International Journal of Environment \& Waste Management 2(1): 111-124.

9. McGann OJ, Bingham PA, Hand RJ, Gandy AS (2012) The effects of $\gamma$-radiation on model vitreous waste forms intended for the disposal of intermediate and high-level radioactive wastes in the United Kingdom. Journal of Nuclear Materials 429: 353-367.

10. Bingham PA, Hyatt NC, Hand RJ (2012) Vitrification of UK intermediate level radioactive wastes arising from site decommissioning: property modelling and selection of candidate host glass compositions. European Journal of Glass Science \& Technology A 53(3): 83-100.

11. Herrington P, Kvatch I, O'Halloran K (2006) Assessing the environmental effects of new and recycled materials in road construction - Proposed Guidelines. Land Transport New Zealand Research Report 306: 1-71.

12. Imteaz MA, Ali MMY, Arulrajah A (2012) Possible environmental impacts of recycled glass used as a pavement base material. Waste Management and Research 30(9): 917-921.

13. Department of Environmental Quality (nd.). Recycling glass in Montana. Accessed 14 ${ }^{\text {th }}$ March 2020. https://deq.mt.gov/Land/Recycle/Glass.

14. Frankel GS, Vienna JD, Lian J (2018) A comparative review of the aqueous corrosion of glasses, crystalline ceramics, and metals. npj Material Degradation 2: 15. 